\title{
THE MAKING OF THE TITULAR NATION ENGINEERS IN SOVIET LITHUANIA AND LATVIA (FROM THE END OF THE 1940S TO THE MID-1950S) ${ }^{1}$
}

\author{
Saulius Grybkauskas \\ (Lithuanian Institute of History)
}

\begin{abstract}
The goals of this article are: 1) to examine the factors that formed the group of Lithuanian engineers compared with the case of Soviet Latvia, and to show what reasons determined the interests of the related historical geopolitical, republic government and institutions of higher education; and 2) to show the significance of training 'excess' Lithuanian engineers in the Soviet Lithuanian government's policy of korenizatsiya (the promotion of members of the titular nation for their careers). The article states that the system that formed in Soviet Lithuania due to the historical geopolitical circumstances, albeit briefly, whereby two universities, in Vilnius and Kaunas, existed until 1950, was exceptionally favourable for the korenizatsiya of specialists compared to other Soviet republics, and the education of titular nation engineers. The 'excess' contingent of engineers trained in the republic's institutions of higher education formed the basis of Lithuanian specialists that allowed the leaders of Soviet Lithuania to send Russian-speaking cadres away from the republic and ensure the korenizatsiya of national cadres.
\end{abstract}

KEYWORDS: Soviet system; nationality policy; higher education; engineers; employment.

\section{Introduction}

The Soviet system was envisaged as planned economic and social development, whereby cadres necessary for the economy were intentionally trained, by calculating in advance the required number of young specialists. This construct was indeed just a goal and ideological phraseology. Higher education documents from that time reflect the stichical aspect of the planned system in the prepa-

${ }^{1}$ The research for this article was part of the project financed by the Research Council of Lithuania 'Engineers in Soviet Lithuania: Socialisation, Professional Education, Activity and Ideology' (MOD-17040). 
ration of specialists, and the problems that continually arose over the need to determine the 'right' cadres, the conflicting interests of different institutions, and the lukewarm implementation in real life of the government's ideological initiatives. For example, the government and the Ministry of Higher Education requested that as many people as possible should commence engineering studies who had work experience, were referred by their factory or plant, or would receive a scholarship from their future employer. However, regardless of the efforts that institutions of higher education made in this direction, the 'factory' contingent only made up a small fraction of the students. The regulations for being accepted into a university were also problematic. Functionaries accountable for planning complained that when a shortage appeared, companies and organisations would declare that there was great demand for this profession which could not be satisfied. However, before the students who were in demand had completed their studies, the need for these professions would have faded, and the question would arise what employment could be found for these graduates.

The Soviet modernisation project was closely associated with progress, technical innovation, and, simultaneously, with professionals who could implement this modernisation, whereby the Soviet ethno-federal structure demanded that the nationality of these specialists be taken into account, and that titular nation specialist cadres in the national republics be educated. However, if it was difficult to determine accurately the demand for specialists in one profession or another, the question of their ethnicity put even more strain on the equation, for they would bring up factors of economic and social effectiveness, as well as factors of national justice, internationalism policy and economic nationalism. A young specialist was not just a Soviet 'builder of the economic foundations of communism', but also an individual expressing Soviet nationality policy and its ethnic institutionalisation, ${ }^{2}$ who had to embody not only the abstract universalism of Soviet modernity, but also the new, specifically titular, Soviet nation's progress and achievements, in comparison with the former 'bourgeois' order. Nonetheless, the nationality aspect of educating engineers was not researched or presented in publications in the Soviet years, because raising this problem on its own could

${ }^{2}$ For more about the institutionalisation of nationalism in the Soviet years, see: R. Brubaker, Nationalism Reframed. Nationhood and the National Question in the New Europe (Cambridge, 1996), pp. 26-40. 
have aroused suspicions of nationalism. That is why we are limited to general publications that were often published by institutions of higher education that trained engineers and had to provide an account of their activities in this field in Lithuania. One such publication is a book published in 1979 by Marijonas Martynaitis, the rector of Kaunas Polytechnic Institute (KPI). ${ }^{3}$

Once independence was restored in Lithuania, historians began to turn their attention to the ethnic policy in the Stalinist years, ${ }^{4}$ and to the collision of economic interests between the ministries of the Soviet Union based in Moscow and a republic's nomenklatura in the late Soviet years. ${ }^{5}$ However, the specifically ethnic aspect of training engineers has not been discussed in academic literature. On the other hand, the theme does feature in the memoirs of former Soviet figures. The rise of Lithuanian engineers in the Soviet years, the regionalisation of the economy they initiated, and the even development of industry across the republic, dominated in the memoirs of these former Soviet figures, becoming matters of pride. ${ }^{6}$ Studies by former employees of the KPI question these narratives, sometimes by highlighting the negative role of the Soviet ideologues who worked at the KPI and in the nomenklatura government. These studies nonetheless enrich rather than critically evaluate the memories of the former nomenklatura. For example, both former Party figures and their opponents had a very favourable opinion of the activities of Kazimieras Baršauskas, the rector of the KPI. ${ }^{7}$ But we can take a deeper look at the training of engineers and the dynamics of this process, to try to evaluate not only the personal efforts that are described today as an expression of the national patriotism of the Lithuanian nomenklatura, but also to grasp the outcomes of the Soviet institutional structure, and even the interwar period's complicated geopolitical situation, on social and economic development in the Soviet period.

${ }^{3}$ M. Martynaitis, Kauno Antano Sniečkaus Politechnikos institutas (Vilnius, 1979).

${ }^{4}$ R. Laukaitytè, Stalininis režimas Lietuvoje 1944-1953 metais (Vilnius, 2014).

${ }^{5} \mathrm{~S}$. Grybkauskas, Sovietine nomenklatūra ir pramonès valdymas Lietuvoje 1965-1985 metais (Vilnius, 2011); V. Ivanauskas, Lietuviškoji nomenklatūra biurokartineje sistemoje: tarp stagnacijos ir dinamikos (1968-1988) (Vilnius, 2011).

${ }^{6}$ See, for example, the memoirs of A. Brazauskas: Ir tuomet dirbome Lietuvai (Vilnius, 2008).

${ }^{7} \mathrm{~A}$. Tamašauskas, Iš Kauno universiteto politechnikos instituto praeities. Komunistu partinès organizacijos raidos ir veiklos apžvalga (Kaunas, 2000). 
Not only were the intentions and goals of different government institutions important, there were also practical methods for implementing these goals. That is why, when we speak specifically about the situation of Soviet Lithuania, the question may arise what justification could the republic's institutions give during the period of Stalin's rule for more engineers, if Lithuania's industrialisation was still so weak? And in reverse, when a new factory was built, it would need new specialists to work there, while the routine for implementing production plans did not allow enough time for graduates from the KPI to complete their studies and defend their diplomas. Engineers from other republics who had already graduated and were looking for employment could exploit this vacuum of specialists, thereby disrupting the education plans for Lithuanian engineers.

During the Soviet years, engineers made up the largest group of specialists with a higher education. Their number and percentage started to grow rapidly in the 1940s and 1950s, when the number of engineers caught up with and exceeded that of doctors, who until then had been the leaders. According to statistical data, there were 1,700 engineers working in Lithuania in 1950, and 3,700 by 1955. If engineers made up only 16.7 per cent of all specialists with a higher education in 1950, then by 1955 this figure reached 20.9 per cent. In 1950 , doctors ( 24.5 per cent) were still ahead of engineers. However, in 1955 engineers became the largest social group with a higher education (that year, doctors made up 19.8 per cent of specialists with a higher education). ${ }^{8}$ Engineers maintained their leading position in subsequent years as well. According to statistical data from 1983, there were 65,800 engineers that year among the 189,100 specialists overall who had a higher education (34.5 per cent). ${ }^{9}$ That is why it is important to examine more closely this social group of engineers and its formation. Knowing that the ethnical composition of engineers in other republics was for need more diverse, due to technological universalism and national policy factors, and that members of the titular nation were not the dominant group, it is important to evaluate the situation in Lithuania, and the formation of its national stratum of engineers in the early stages of the Soviet years.

${ }^{8}$ LSSR Central Statistical Board information sent to M. Šumauskas, the chairman of the LSSR Council of Ministers, 1956, Lietuvos centrinis valstybès archyvas (LCVA) Lithuanian Central State Archives, R-754, ap. 4, b. 4098, 1. 3.

${ }^{9}$ Lietuvos TSR liaudies ūkis 1983 metais (Vilnius, 1984), p. 135. 
This article seeks: 1) to examine the factors that formed the group of Lithuanian engineers, and to show what reasons determined the related historical geopolitical, republican government and higher education institutions' interests; and 2) to show the importance of training 'excess' Lithuanian engineers to the Soviet Lithuanian government's policy of korenizatsiya (the promotion of members of the titular nation in their careers).

The presumption is that the beginning of the Lithuanianisation ${ }^{10}$ of engineers was not done at the initiative of the leaders of Soviet Lithuania, but at the initiative of lecturers and directors of institutions of higher education, primarily the rector of Kaunas University, Juozas Kupčinskas, and after its closure and the founding of the KPI in 1950, the rector Kazimieras Baršauskas. ${ }^{11}$ On the other hand, even though the importance of these figures is highlighted, their actions are interpreted not only as patriotic concern for the promotion of national cadres, but also as the representation of the interests of Kaunas University and the KPI as an institution of higher education in the activities of these rectors. At the beginning of the 1950s, the KPI had around 2,000 students enrolled in studies, ${ }^{12}$ which was considered the minimum for a contingent by the USSR Ministry of Higher Education and other institutions. The directors must have known that a smaller number of students would have threatened the school's survival.

\section{The first initiatives to Lithuanianise engineering specialists in Soviet Lithuania}

Until 1959, the most important schools of higher education were directly under the USSR Ministry of Higher and Specialised Secondary

${ }^{10}$ For the purposes of this article, the concept of Lithuanianisation and reLithuanianisation is not taken to mean assimilation, but the process of ethnic Lithuanians becoming engineers. Nonetheless, once they completed their engineering studies and found employment in enterprises and organisations, these young specialists pushed out a number of foreign (usually Russian-speaking) employees. However, this number was not so high compared to the new positions being created as a result of industrialisation. That is why the Lithuanianisation (or re-Lithuanianisation) of engineers was not the displacement of foreigners, so much as the entrenchment of Lithuanians in leading engineering positions, thereby limiting the domination of foreign engineers, and the possible arrival of specialists from other republics.

${ }^{11}$ Kazimieras Baršauskas (1904-1964) was dean of the Faculty of Technology (1946-1947) and Electrotechnology (1947-1950) at Kaunas University. When the KPI was established in 1950, he served as its rector until his death in 1964.

12 See: M. Martynaitis, et al., Kazimieras Baršauskas (Vilnius, 1969). 
Education, ${ }^{13}$ which formulated allocation plans for young specialists to meet the demands of organisations across the whole Soviet Union. Some KPI graduates were sent to work far away from Lithuania. These young specialists were not happy with these placements, and would search for ways to avoid this kind of 'exile'. Young Communist leaders at the KPI would criticise graduates who tried to evade their placements, or who applied 'bourgeois nationalist' provisions and avoided carrying out their 'internationalist duty' by taking up their allocated position in other republics. ${ }^{14}$ This lack of an 'internationalist duty', in order to avoid having to work beyond the republic's borders, was typical of KPI graduates until the middle of the 1950s, when the USSR Ministry of Higher Education ultimately abandoned the practice, and allowed young specialists to remain in Lithuania. For example, in 1953 when Stalin died, rumours spread that graduates could look for work in Lithuania, which is what most hurried to do. However, Kazimieras Baršauskas, the rector of the KPI, himself demanded that organisations that had accepted young graduates retract their offers, and that the specialists be sent to places of employment foreseen by the Soviet Union's young specialists' allocation plan. ${ }^{15}$ As we can see from the protocol for referring KPI graduates who completed their studies in the spring of 1953, there were 315 students who had graduated at the time. 88 graduates of this contingent received a placement outside Lithuania. ${ }^{16}$ Many of the young engineers who were allocated positions outside Lithuania tried to avoid working in other republics. There were 76 names on the list of KPI graduates for that year who had not left to work in other 'brotherly republics', including Edvardas Gudavičius, today a

${ }^{13}$ Henceforth, the USSR Ministry of Higher Education. Some of the institutions of higher education in the USSR were under the jurisdiction of other agencies belonging to other, usually manufacturing, ministries.

${ }^{14}$ Meeting protocol of the Kaunas Polytechnic Institute's Young Communist primary organisation, 23 March 1952, Lietuvos ypatingasis archyvas (LYA) Lithuanian Special Archives, f. 9885, ap. 1, b. 6, 1. 81.

${ }^{15}$ Letter from K. Baršauskas dated 12 October 1953 to A. Sniečkus, the first secretary of the CPL CC, M. Gedvilas, the chairman of the LSSR Council of Ministers, and Kasnauskaite, the Kaunas secretary of the CPL, LCVA, f. R-754, ap. 4, b. $3205,1.101$.

${ }^{16}$ Graduate Allocation Commission protocol regarding KPI students who completed their studies on 11-13 May 1953, Kaunas Regional State Archives (KRVA), f. R-1260, ap. 1, b. 108, 1. 50; list of young specialists who graduated from the KPI in 1953 and were referred to positions in other Soviet republics, May 1953, Ibid., 1. 67-70. 
famous historian, who was referred to work as an engineer at the Kandalaksha mechanical plant in the Murmansk Oblast. ${ }^{17}$ His memoirs reflect perfectly the situation of a young specialist at that time, the choices that existed, and the attempts to try to avoid working far from Lithuania: 'I graduated from the Polytechnic Institute in 1953. The case of Lavrentiy Beria that became so public at the time meant we could all receive our diplomas straightaway. However, that placement hung over my head like a sword of Damocles ... One fine day, the director at the Pergale factory where I worked received an order to dismiss me, so that I must go and work where I had been ordered a placement. I am lucky that he was such a good person. He called me into his office, and said: 'I cannot keep you on here at my factory. You have several options: you can sign a declaration and "dive into the water" [go off the radar]. However, if they find you, the situation will just be repeated. I cannot say how long you can go on evading your placement in this way. In most cases, it will depend on the good-will of the organs of local government, and how determined the factory that you're to work at is. In the worst case, the militsia could come to your home. But even then, there is a way out. My advice is to find work at one of the Tractor Machinery Stations (TMS) in the Kaunas region. ${ }^{18}$ The fact that Gudavičius avoided 'exile' to the Murmansk Oblast by working for some time at the TMS (these stations were prioritised at the beginning of Khrushchev's rule, which is probably why working in one could become a temporary respite for not taking up a placement) appears to show that young engineers did find ways of avoiding 'exile' to distant parts of the USSR.

Sending young specialists from Lithuania to work in other republics was typical during the entire period under research, and not just in the years mentioned. Interestingly, it was not the leaders of Soviet Lithuania who were the first to ask why young, recent graduates of engineering were not allowed to stay in the republic, but the directors of Kaunas University. In March 1948, Juozas Kupčinskas appealed in writing to the Council of Ministers: 'Each day numerous declarations come in from various agencies to send graduate specialists outside

${ }^{17}$ List of specialists who graduated from the KPI in 1953 and were referred to work in enterprises outside Lithuania, and yet found employment in Lithuania, LCVA, f. R-754, ap. 4, b. 3205, 1. 102-104.

${ }^{18}$ E. Gudavičius, A. Švedas, Visa istorija yra gyvenimas. 12 sakytinès istorijos epizodų. Edvarda Gudavičiu kalbina Aurimas Švedas (Vilnius, 2008), p. 93. 
the LSSR, while there are very few placements within the LSSR. The commission for the allocation of graduates that is charged with referring specialists outside the LSSR faces considerable difficulties, because those who have graduated from university, for various reasons, such as their material and family situation, poor language skills, and so on, often refuse to go to the place they have been referred to. ${ }^{19}$ At the end of the letter, Kupčinskas reproaches the republic's government: 'I get the impression that the organs concerned in the republic have not informed the USSR Ministry of Higher Education about the shortage of young engineering cadres in the Lithuanian SSR, and that the graduate allocation plan was created without taking into account the concerns of our republic.' There are several points worth drawing attention to here. First of all, this is probably the first letter in which concern over the shortage of young specialist engineers in Soviet Lithuania is actually expressed. Secondly, this concern is not expressed by the leaders or government institutions of Soviet Lithuania. The first person to bring up 'our republic's concerns' was the rector of Kaunas University. Thirdly, he does so by contradicting himself in the same letter: as has been mentioned, he writes at the start that the republic's institutions and enterprises are enquiring about receiving young specialists. How could it be that, as Kupčinskas claimed, 'there is a shortage of engineering cadres in the Lithuanian SSR,' if the republic's institutions and organisations did not want to employ them? After renewing its activities in the autumn of 1944, and until its reorganisation into the Kaunas Polytechnic Institute in 1950, only 385 engineers graduated from Kaunas University. ${ }^{20}$ However, it appears that even this figure was too high for the republic's government agencies and manufacturing organisations. Nonetheless, regardless of these contradictions, the republic's government 'believed' the words of the rector of Kaunas University, and appealed to Moscow about this matter. One detail that should be noted is that Kupčinskas' letter to the Council of Ministers is dated 22 March 1948, while already on 27 March, Motiejus Šumauskas, the chairman of the LSSR State Planning Committee, sent a response to the letter to the LSSR government, with a three-page draft for

${ }^{19}$ Letter from Juozas Kupčinskas, dated 22 March 1948, to V. Niunka, the deputy chairman of the Lithuanian SSR Council of Ministers, LCVA, f. R-754, ap. 4, b. $1414,1.94,95$.

${ }^{20}$ M. Martynaitis, Kauno Antano Sniečkaus Politechnikos institutas (Vilnius, 1979), p. 83. 
the letter to be sent to the USSR Ministry of Higher Education. ${ }^{21}$ The significance of personal networks can be seen in this interaction between the leaders of Kaunas University and the republic's government. Juozas Kupčinskas, the rector of Kaunas University, and Kazimieras Baršauskas, the first rector of the KPI, were good friends ever since they attended the gymnasium in Marijampole during the interwar years, and shared a room there while completing their studies. ${ }^{22}$ The gymnasium was known for the leftist stance of its teachers and students, because many of those who had worked or studied there later ended up in high positions in the Soviet period. For example, Juozas Žiugžda, who was a teacher there, became the vice-president of the LSSR Academy of Sciences and the director of the Institute of History. Michalina Meškauskienė, ${ }^{23}$ who worked as the head of the Department of Culture and Health Protection in the Lithuanian SSR Council of Ministers, and later as the minister for cinematography, also studied at the gymnasium. According to historian Marius Ėmužis, even prior to the Second World War, Meškauskiene established and maintained close ties with Mečislovas Gedvilas (the chairman of the LSSR Council of Ministers in 1944-1956) and Justas Paleckis (the chairman of the Presidium of the Supreme Soviet of the LSSR in 1940-1967). ${ }^{24}$ These connections and old friendships could have been a fertile ground for discussing ideas, agreeing on joint actions, and acting, without having to go through long-drawn-out bureaucratic deliberations.

To ensure that specialists could stay in Lithuania, a demand for specialists had to be created, even if that kind of demand was lacking because of the relatively weak industrialisation of the country. On the other hand, both Juozas Kupčinskas, the rector of Kaunas University, and later, after establishing of KPI in 1950 - its rector Juozas Baršauskas, felt the pressure from society. If specialists were only sent away to other republics, that meant engineering studies were not a very attractive option, and problems could arise regarding the formation of a contingent. Looking at it from this perspective, after

${ }^{21}$ Letter from M. Šumauskas, dated 27 March 1948, to the LSSR Council of Ministers, LCVA, f. R-754, ap. 4, b. 1414, 1. 86.

${ }^{22}$ M. Martynaitis, et al., Kazimieras Baršauskas, p. 15.

${ }^{23}$ Ibid., p. 20.

${ }^{24}$ M. Ėmužis, Sovietu Lietuvos valdantysis elitas 1944-1974 metais: tarpusavio ryšiai ir ju raiška (The Ruling Elite in Soviet Lithuania in 1944-1974: Inter-Relations and their Expression), Doctoral dissertation, Vilnius University, 2016, p. 117. 
assessing the activities of Kaunas University, the USSR Ministry of Higher Education planned to reduce the places on first-year courses. In May 1950, Kupčinskas complained in a letter to Gedvilas and Šmauskas that Kaunas University had received a plan for student enrolment from the USSR Ministry of Higher Education that 'did not suit the requirements of the republic's economy as far as the training of engineering cadres was concerned'. Again, note the rhetoric used: the necessity for ensuring the growth and support of the contingent is not discussed, but an allusion is made to meeting the interests of the republic's economy. This time, even the more senior leaders in the republic could not influence the provisions of the all-Union ministry: it suggested increasing the number of builders at the expense of training more architects.

When discussing the question of the Lithuanianisation of engineers in Soviet Lithuania, it is important to take into account the geopolitical conditions that existed at the time, and the specific historical legacy, which differed from neighbouring republics. One fundamental difference cannot be overlooked: there were two state universities in Lithuania right until 1950, whereas other republics, except for Russia and Ukraine, had only one each. One national university per Soviet republic was a feature of Soviet national policy. According to the philosopher Bronislovas Genzelis, 'This kind of reform was influenced by the research policy of the Soviet Empire: each republic's capital city had to have a university (only in Estonia was it in Tartu, in response to the tradition). All the republics in the union, except for the Russian Federation and Ukraine, had one university each. The question of whether institutions of higher education had to be established or liquidated depended completely on Moscow, or, more precisely, on its mercy. ${ }^{25}$

And even though Kaunas University was closed in 1950 and reorganised into Kaunas Polytechnic Institute and the Kaunas Institute of Medicine, this did not decrease but only strengthened the training of engineering cadres. You could even say that when the LSSR recovered Vilnius, along with the most important university in the republic, and having inherited the independent academic environment from Kaunas, an exclusive balance of development in higher education was created. Its importance is quite evident when comparing it with the situation in Latvia. Even though industriali-

${ }^{25}$ B. Genzelis, 'Vytauto Didžiojo universiteto atkūrimo peripetijos', Kauno istorijos metraštis, 12 (2012), p. 203. 
sation in that republic was much more advanced than in Lithuania, the establishment of a polytechnic institute there was problematic. In a letter to the government of the Soviet Union, Vilis Lacis, the chairman of the Latvian SSR Council of Ministers, wrote that the USSR Ministry of Higher Education was not seen to be implementing the decree of 30 June 1953 of the government of the Soviet Union regarding the establishment of Riga Polytechnic Institute or the construction of its buildings in 1954-1956, leaving the faculties of Mechanical and Engineering Construction at the University of Latvia as the only institutions in the republic where engineers could obtain a degree. Riga Polytechnic Institute was only established in 1958. As we shall see later, the Soviet Latvian government often wrote to institutions of the Soviet Union regarding the insufficient number of engineers being trained. The fact that it was difficult to establish a new institution of higher education is also evident from the examples of other republics. As can be gathered from the documents of the USSR Ministry of Higher Education, letters from leaders of Soviet republics requesting the establishment of polytechnic institutes in their republics were rather frequent; however, the ministry rarely agreed with these kinds of initiatives. On the contrary, the leaders of Soviet Lithuania did not need to worry about this. When Vilnius became the capital of the Lithuanian SSR, it also recovered the oldest institution of higher education in Lithuania, which is why until 1950 two universities operated in the Lithuanian SSR, in Vilnius and in Kaunas. The reorganisation of the latter into the KPI and the Institute of Medicine was a much simpler process than the establishment of a new polytechnic institute. In his memoirs, Yurii Zhdanov, the former head of the Department of Science of the CPSU $\mathrm{CC}$, claimed that even Stalin himself advised him not to hurry to open new institutions of higher education, but to focus more on improving the existing ones. ${ }^{26}$ It is unlikely that the government of the Soviet Union would have agreed to establish the KPI in 1950 had Kaunas University not already existed.

Institutions of higher education should not be seen as passive actors, simply carrying out the government's orders. Quite the opposite, they were organisations with their own interests, the realisation of which was strongly influenced by the development not only of the higher education sector, but of society and the economy as well. So,

26 Ю.А. Жданов, Взгляд в прошлое: воспоминания очевидия (Ростов-наДону, 2004). 
it can be said that the fundamental basis behind the successful Lithuanianisation of engineers lay not so much in the political intuition of Lithuania's leaders as in the complicated geopolitical situation left over from the past, which naturally presupposed the existence of two intellectual and political centres, or two capital cities.

\section{The korenizatsiya of young engineers in Soviet Latvia and in other republics of the USSR}

The attempt to keep young specialists in their own republics was a phenomenon that existed not only in Soviet Lithuania, but also in neighbouring Latvia and other republics. In 1951, the leaders of Kazakhstan complained to Molotov, the chairman of the USSR Council of Ministers, that their republic needed specialists with a higher education, especially engineers. ${ }^{27}$ However, the USSR Ministry of Higher Education and the CPSU CC apparatus did not agree to keep more specialists in the republic than was outlined in the plan, alleging that they were required in other republics, especially in Central Asia. ${ }^{28}$ The CPSU CC apparatus calculated that 26 per cent of specialists completing their studies in Kazakhstan that year would be sent to other republics.

The leaders of Soviet Georgia devised a radical way to solve the problem of the shortage of specialists. On 7 September 1951, K. Charkviani, the secretary of the Central Committee of the Communist Party of Georgia, announced to P. Ponomarenko, the secretary of the CPSU CC, that the republic needed over a thousand engineers; however, that year the USSR Ministry of Higher Education was planning to leave only 161 young engineers in the republic. It is interesting that not only did the government of Soviet Georgia devise its own solution, going against the plan outlined by the USSR Ministry of Higher Education, to leave as many as 422 specialists out of the 597 that were expected to complete their studies, ${ }^{29}$ but also that the government of the Soviet Union, including the same USSR Ministry of Higher Education, approved this 'self-willed' decision

${ }^{27}$ Letter from the USSR State Planning Committee, dated 5 July 1951, to G. Malenkov about the request from the government of Kazakhstan, Russian State Archive of Social and Political History (RGASPI), f. 17, ap. 133, b. 204, 1. 150, 151.

${ }^{28}$ Letter from Yurii Zhdanov, the head of the CPSU CC Department of Science, dated 23 October 1951, to G. Malenkov, ibid., 1. 153.

${ }^{29}$ Letter from K. Charkviani, the Georgian CC secretary, dated 7 September 1951 , to P. Ponomarenko, the CPSU CC secretary, RGASPI, f. 17, ap. 133, b. 204, 1. 173. 
made by the bold republic. ${ }^{30}$ It could be that this outcome was based on the personal, paternalistic bonds of the republic's leaders with the highest authorities in the USSR at the time (Stalin and Beria), which is why functionaries from the CC apparatus and the USSR Ministry of Higher Education did not dare to make the situation worse, did not apply sanctions, and 'believed' in the Georgians' arguments that a sizeable percentage of the graduates had already started working in Georgia, and so it would be wrong to discharge them and send them away to work elsewhere.

The leaders of Soviet Latvia also tried to keep their young specialists in the republic. It is interesting to note the actions taken by different government institutions in Lithuania and Latvia. In Lithuania, there were government institutions, such as the National Statistical Committee of the Lithuanian SSR, which urged abiding by the Soviet Union decree of 30 August 1954 to focus on increasing the number of technicians with a specialist secondary education rather than on engineers with a higher education. The most important lobbyists in favour of boosting the number of engineers with a higher education were, as was mentioned before, the rectors of Kaunas University (which later became the KPI). Not only the rectors, but lecturers as well, actively supported and campaigned for engineering studies. In his memoirs, Apolinaras Džiaugys, a KPI graduate and contemporary of Algirdas Brazauskas, a later president of Lithuania, recalls how lecturers urged their students not to be too modest, and to pursue careers and positions in management. According to him, they would say that the ministries were full of functionaries wearing army boots, and engineers should not hesitate, for they had a much better understanding of their profession once they had completed their studies than anyone in the government. ${ }^{31}$

If in Lithuania it was the KPI community that was the most active supporter of the Lithuanianisation of engineering cadres, in neighbouring Latvia, government institutions were more active than the University of Latvia. Republic's government representatives made plans, and asked the USSR Ministry of Higher Education to provide for a higher intake. For example, in the 1956-1957 academic year,

${ }^{30}$ Letter from P. Ponomarenko, M. Jakovlev, V. Stoletov and V. Alekseev, dated 21 September 1951, to G. Malenkov, tibis., 1. 188. Ponomarenko's signature does not appear on the letter.

${ }^{31}$ Interview with Apolinaras Džiaugys by S. Grybkauskas, 1 August 2017. From the author's papers. 
the University of Latvia planned to accept 225 first-year regular students in the faculties of Mechanics and Construction Engineering, while the republic's State Planning Committee recommended 275. Nonetheless, the USSR Ministry of Higher Education envisaged only 175 places, which left the Latvian government very dissatisfied, and prompted it to write to Moscow.

On 8 March 1956, Vilis Lacis, the chairman of the Latvian SSR Council of Ministers, wrote to the USSR Council of Ministers regarding an increase in the number of places for engineering students. The head of the government of the Latvian SSR resented the fact that the plans of the USSR Ministry of Higher Education foresaw a reduction in enrolment in the faculties of Mechanics and Construction Engineering at the University of Latvia, which were the only faculties in the republic training engineers. According to him, even though Latvia needed 3,400 engineering specialists for 1956, first-year course intake in the faculties mentioned for the 1956-1957 academic year had been reduced to 175 , even though the republic's State Planning Committee had foreseen 250 places. ${ }^{32}$

Not only did the leaders of Soviet Latvia ask the government of the Soviet Union to increase the number of places for engineering students, but also to let engineering graduates work in the republic, and it highlighted the necessity to employ Latvian specialists to work in Latvia. In the summer of 1952, Janis Kalnberzinš, the first secretary of the CC, wrote to N. Bulganin, the deputy chairman of the USSR Council of Ministers. In his letter, he wrote that Latvian ethnic labourers worked at the Riga Diesel Plant, which was under the USSR Ministry of Heavy Industry, but there were not enough Latvian engineers. Kalnberzinš requested that the USSR Ministry of Higher Education allocate ten specialist graduates from the Faculty of Mechanics at the University of Latvia to work at the Riga Diesel Plant. ${ }^{33}$

More comprehensive summarised data about the allocation of University of Latvia graduates to work in other republics was given by Vilis Lacis, the chairman of the Latvian Council of Ministers, in the previously mentioned letter of 8 March 1956 to the USSR

32 Draft of the letter from V. Lacis to the USSR Council of Ministers dated 8 March 1956, Latvian State Archives (LVA, Latvijas Valst Arhivs), f. 270, ap. 2, b. $5657,1.16$.

${ }^{33}$ Letter from J. Kalnberzinš, dated 4 July 1952, to N. Bulganin, LVA, f. PA -101, ap. 15, b. 98, 1. 193, 194. 
Council of Ministers. He claimed that each year, a large number of specialists who could speak Latvian and had graduated from the republic's university were being sent to work in other republics. According to Lacis, in 1952-1955 alone, of the 524 specialists who had graduated from the faculties of Mechanics and Construction Engineering, 134 (26 per cent) were sent away to work in other republics. ${ }^{34}$ Soviet Latvia's dissatisfaction with the system for training engineers and their further placement was mentioned in another letter from Vilis Lacis, dated 23 March, this time sent to the USSR Ministry of Higher Education. Lacis added that as the republic needed over 3,000 engineers, of the 200 graduates due to complete their studies in 1956 at the two engineering faculties mentioned, the ministry was sending as many as 107 away to work in other republics. The leader of the government of the Latvian SSR was angry that the destinations to which young Latvian specialists were being sent included cities that had their own institutions of higher education, such as Minsk, Vilnius and the Leningrad Oblast. ${ }^{35}$ The appendices, drafts and material revealed what areas of specialisation and where the 107 graduates from the University of Latvia were being sent to. In this way, of the 45 engineers who would graduate in civil construction in 1956, as many as 35 were referred to other republics. Out of this total, the largest group (eight graduates) were sent to Nizhny Tagil in the Sverdlovsk (present-day Yekaterinburg) Oblast in the Urals. The other destinations included Tula and Lipetsk, the Kustanaiskaya and Pavlodar oblasts in Kazakhstan, the Murmansk Oblast, and others. And even though Kaunas Polytechnic Institute also trained specialists in this field, two graduates from the University of Latvia were nonetheless sent to work in Kaunas. ${ }^{36}$ Two graduates in machine production and metal cutting machine technology were sent to work in Vilnius, and four cellulose and paper production technicians went to the Kaunas, Klaipeda, Vilnius and Trakai districts. Of the 30 graduates specialising in electricity stations and networks, 18 were sent to other republics. The ratio was somewhat smaller for other specialisations. Agricultural construction

${ }^{34}$ Draft of the letter from V. Lacis to the USSR Council of Ministers dated 8 March 1956, LVA, f. 270, ap. 2, b. 5657, 1. 17.

${ }^{35}$ Letter from V. Lacis, dated 23 March 1956, to V. Eilutin, the USSR minister for higher education, LVA, f. 270, ap. 2, b. 5657, 51.

${ }^{36}$ Note about the allocation of graduates from the technical faculties of the University of Latvia for 1956, LVA, f. 270, ap. 2, b. 5657, 1. 53. 
was the only area where a majority of graduates would stay in their home republic (only three out of the 18 graduates were sent away). ${ }^{37}$

The letters from Lacis did cause the government of the USSR and the Ministry of Higher Education to react. A letter dated 8 March bears the visa of Molotov, the chairman of the USSR Council of Ministers, ordering the USSR Ministry of Higher Education to solve the problems Lacis highlighted in his appeals. In response to the order from the government of the Soviet Union, Prokofiev, the USSR deputy minister of higher education, promised to increase intake by the faculties mentioned by 50 places. ${ }^{38}$ In its reply to Lacis, the State Economy Commission of the USSR Council of Ministers stated in a letter dated 23 March 1956 that it was not against allowing graduates from the University of Latvia to stay and work in their republic, and that having come to an agreement with the USSR Ministry of Higher Education, it had sent information about this to the University of Latvia. ${ }^{39}$

Thus, it can be said that letters from leaders of republics regarding an increase in enrolment for engineering studies, and keeping graduates to work in their own republics, ultimately achieved their goals. The problems were raised at a politically sensitive time, at the beginning of the spring of 1956, soon after Khrushchev's speech at the 20th Congress of the CPSU about Stalin's crimes. Information was gathered and distributed especially for this congress about Stalin's earlier disagreements with Lenin about the future state structure of the USSR, showing that Stalin had only offered autonomy to the peripheries of the former empire. So it can be said that letters from the Soviet republics about training national cadres and engineers hit their target, and complied with the decentralisation of political authority demonstrated by Khrushchev's government. Feeling the effects of the changing political climate, in 1956 the USSR Ministry of Higher Education revoked its practice of referring graduates to work in other republics. V. Eliutin, the minister of higher education of the USSR, replied to Lacis, stressing that, 'With regard to the

${ }^{37}$ Note about the allocation of graduates from the technical faculties of the University of Latvia for 1956, LVA, f. 270, ap. 2, b. 5657, 1. 52.

${ }^{38}$ See Molotov's visa dated 13 March 1956 with the text of Lacis' letter dated 8 March 1956, LVA, f. 270, ap. 2, b. 5657, 1. 26.

${ }^{39}$ Letter from E. Andreev, the deputy chairman of the USSR Council of Ministers State Economic Commission, dated 18 April 1956, to V. Lacis, LVA, f. 270, ap. 2, b. $5657,1.59$. 
referral of graduates from the University of Latvia, the Ministry has informed you in its letter dated 4 April 1956 about the measures taken to keep graduates from the University of Latvia completing their studies in 1956 to work in their republic. The USSR Ministry of Higher Education shall continue to follow these guidelines when allocating placements for graduates from the University of Latvia. ${ }^{40}$

It was not only the leaders and the apparatus of the Latvian Council of Ministers that became involved in solving the problem of training engineers. Even though the question of national cadres could have appeared relevant to the national communists who were then taking up posts in the government, the republic's Party leaders also did not shy away from the issue, including Arvids Pelše, the secretary for ideology of the Central Committee at that time. Later, in July 1959, he was an active participant in purging the national communist leadership, and became first secretary himself. However, as we learn from archive documents, the education of engineering cadres was also within his sights. I. Ivanova, the cultural affairs reporter from the Latvian Council of Ministers, noted on a document prepared by the government called 'Recommendations for the Training of Specialists at the University of Latvia and Pedagogical Institutes in 1956-1960' that: 'The matter was discussed at a meeting with the CPL CC secretary, Com. Pelše, on 10 May 1956. The decision was made to prepare a letter to the USSR Council of Ministers. ${ }^{41}$

\section{Problems encountered in employing young engineers in Lithuania in the mid-1950s}

Graduates from Lithuania were also allowed to remain in their republic. Paradoxically, this possibility, outlined in Resolution No 1995 passed on 1 December 1955 by the CPSU CC and the USSR Council of Ministers, had a major impact not only on the training of specialists, but also on the political development of the republic. At that time, Khrushchev was very disappointed with the results of the agricultural sector in the Baltic republics, and he criticised the local governments for their poor leadership. Moscow's Party apparatus sent Soviet functionaries brigades to Lithuania, Latvia

${ }^{40}$ Letter from V. Eilutin, the USSR minister for higher education, to V. Lacis, dated May 1957 (the exact day is not visible due to the way the document was filed), LVA, f. 270, ap. 2, b. 5657, 1. 29.

${ }^{41}$ LVA, f. 270 , ap. 2, b. 5657, 1. 20. 
and Estonia to help the local leaders. One of the outcomes of the centre's disappointment was the dismissal of Mečislovas Gedvilas, the leader of the LSSR government, followed by the reinstatement of the institution of 'governor-general', a representative from Moscow serving as the second secretary of the CPL CC. This post was filled by the former CPSU CC apparatus staff member Boris Sharkov. ${ }^{42}$ The important resolution mentioned earlier passed by the CPSU CC and the USSR Council of Ministers on 1 December 1955 came about as a result of this 'assistance', or more likely as a result of the pressure put on Antanas Sniečkus' government. Even though the document, with as many as 36 points, applied mostly to agricultural problems, some sections concerned the increase in the production of construction materials and irrigation pipes, and the provision of cadres needed for this work. Point No 25 also ordered: 'To oblige the USSR State Planning Committee and the USSR Ministry of Higher Education to ensure that in its specialist allocation plans for 1956-1958, all construction and hydro-technology engineers completing higher education studies in the Lithuanian SSR are not sent away to work outside the Lithuanian SSR. ${ }^{43}$ The primary concern of the resolution was not Lithuania's engineers, but rather the situation in the agricultural sector: in order to bring about improvement, construction engineers and hydro-technology specialists with a higher education qualification were allowed to remain in the republic on this occasion. Interestingly, even when the Soviet Union resolution mentioned was passed, the question of the employment of KPI graduates in Lithuania still remained unclear. A typical bureaucratic routine came into play, which managed to ignore even this CPSU CC resolution. In April 1956, a letter from Sumauskas, the chairman of the LSSR government, and Sharkov, the second secretary of the CPL CC, to Eliutin, the USSR minister for higher education, expressed anger over the fact that the Soviet Union resolution mentioned had been completely ignored in the allocation of KPI graduates. As many as 97 construction and hydro-technology engineers (or 65 per cent of those graduating in the field) were being sent away to work outside Lithuania's borders according to the

${ }^{42}$ S. Grybkauskas, 'Imperialising the Soviet Federation? The Institution of the Second Secretary in the Soviet Republics', in: Ab Imperio, November 2014, No 3, pp. 267-292.

${ }^{43}$ The resolution of the CPSU CC and USSR Council of Ministers No 1995 of 1 December 1955 'On Measures for Improving the Agricultural Sector in the Lithuanian SSR'. E. Zubkova, Sovetskaya model ekonomiki: soyuznyi centr $i$ respubliki pribaltiki $n 1953$ g. - mart 1965. Dokumenty (Moskva, 2015), p. 658. 
latest allocation plan. ${ }^{44}$ The Soviet Union Ministry of Higher Education reacted promptly to the letter from the republic. In his response, Eliutin stressed to the LSSR leaders that, in accordance with the new resolution, those who were graduating in construction and hydro-technology would indeed be allowed to remain to work in Lithuania. ${ }^{45}$

As a further response to the requests coming from the republics, including the earlier-mentioned reproaches by the government of Soviet Lithuania for non-compliance with the resolution of 1 December 1955 of the CPSU CC and the USSR Council of Ministers, the Soviet Union Ministry of Higher Education allowed specialists in all engineering fields graduating in Lithuania to remain in the republic, and not only construction and hydro-technology engineers. Unlike the situation in Soviet Latvia, where industrialisation was more advanced, it soon became apparent that a number of ministries and enterprises did not want to employ young specialists remaining in Lithuania. At an LSSR State Planning Committee meeting held in August 1956, the chairman Petrov said that 'There is a government resolution in place to employ all young specialists graduating from institutions of higher education and specialised secondary schools in the republic. However, there are ministries and other agencies that refuse to employ these young specialists, even though the number of positions open to specialists with a higher education is far from being filled.' At the meeting, Petrov advised the ministers and representatives from the ministry 'to accept the young specialists more willingly, and not to evade the allocation plan compiled by the State Planning Committee'. ${ }^{46}$ However, ministers of Soviet Lithuania did not want to bend and employ the recommended specialists. K. Kairys, the LSSR minister for milk and meat, announced that 'The training of meat and dairy products specialists must slow down. Our republic no longer needs specialists in this field.' The ministry did agree to employ 21 graduates, and suggested sending the others to neighbouring Estonia, Latvia and Belarus. It is questionable whether Belarus actually needed these specialists, as an analysis of the labour force and a production capacity distribution study conducted in 1962 revealed that in that republic, industrial expansion was seriously

${ }^{44}$ Letter from Šumauskas and Sharkov, dated 11 April 1956, to Eliutin, the USSR minister for higher education, LCVA, R-754, ap. 4, b. 3822, 1. 148.

${ }^{45}$ S. Grybkauskas, M. Tamošaitis, Epochu virsmo sukūriuose. Algirdo Brazausko politine biografija (Vilnius, 2018), p. 42.

${ }^{46}$ LSSR State Planning Committee meeting protocol of 8 August 1956, KRVA, f. R-1260, ap. 1, b. 220, 1. 7-9. 
behind Soviet Union averages; however, the number of specialists with a higher education exceeded union-wide figures. ${ }^{47}$

Other LSSR ministers reacted similarly. Ufimcev, the minister for urban and rural construction, declared that the further training of architects was unnecessary. The ministry needed builders rather than architects. He agreed to employ 30 architects; however, they would not be employed as architects rather as construction engineers. Martynaitis, the LSSR minister for the automobile industry, also stated that 'Road transport engineers are no longer required, and further training in this specialisation is not necessary.' In 1957, the minister agreed to employ only five road transport specialists, "not because they are necessary, but mostly to simplify the work of the State Planning Committee'. In response to this, the chairman of the State Planning Committee also suggested that the minister for construction employ road transport engineers, because their profile also involved construction; however, Ufimcev did not agree to take on these engineers. Petrov was left with no other option than to divide the 30 young road transport specialists left 'without work' as he saw fit, allocating 20 to the LSSR Ministry of the Automobile Industry, and ten to the Ministry of Utilities. The employment of engineers with other specialisations was also more like a negotiation process, whereby the State Planning Committee wanted to find placements for graduates, while ministries made all sorts of excuses and categorically disagreed to accept any new employees. A representative from the Ministry of the Building Materials Industry categorically announced that 'There is no point in training more silicate brick manufacturers; we have nowhere to put them.' He claimed that new production capacity measures were not being introduced. When Petrov suggested taking on 25 silicate brick manufacturers regardless, the ministry agreed to take on no more than ten. ${ }^{48}$

Thus, it can be said that until the middle of the 1950s, the government of Soviet Lithuania frequently asked Moscow to leave as many specialists as possible in Lithuania. However, under the effects of Khrushchev's move towards decentralisation, the USSR Ministry of Higher Education ultimately changed the policy for the centralised

${ }^{47}$ Primary provisions for the distribution of labour in the Belarusian SSR economic district prepared by the USSR State Planning Committee's Labour Distribution Board, 1962, Russian State Archive of the Economy (RGAE), f. 7, ap. 4, b. 63 1. 12.

${ }^{48}$ LSSR State Planning Committee meeting protocol of 8 August 1956, KRVA, f. R-1260, ap. 1, b. 220, 1. 7-9 ibid., R-1260, ap. 1 b. 220, 1.8. 
allocation of graduates, and agreed to keep young engineers in the republic. This left the government of Soviet Lithuania and institutions of higher education with the new problem of under-employment among these specialists.

Nevertheless, we should not look at the over-supply of young engineers as a problem limited to the leaders of Soviet Lithuania alone, but in the broader political context. At the time, the sending away of Russian-speaking functionaries from Lithuania was already well under way. An important basis for this korenisation of the Lithuanian nomenklatura and specialists was the over-production of young Lithuanian specialists. We can see certain social and political tensions, whereby administrators and functionaries at institutions and manufacturing organisations that had arrived in Lithuania at some point in the past on the basis of a referral from the CPSU CC unwillingly accepted young Lithuanian specialists for positions, even though the job descriptions outlined that it was mandatory to have an employee with a higher education degree in engineering in one or another workplace. The 'expulsion' of Russian-speaking functionaries and other specialists from Lithuania had to correlate with the employment of new, Lithuanian, specialists. The government of Soviet Lithuania had to ensure that this change-over in leaders and specialists took place smoothly, and was justifiable (the new specialists had to meet the necessary professional requirements). The campaign of expulsion of Russian speakers raised a number of complaints, before being suspended altogether in 1959, when the CPSU CC passed the resolution 'On the Lithuanian Party Organisation's Work with Cadres'. In 1956, Sniečkus wrote to the CPSU CC: 'We consider it necessary to mention that there are certain reasons stopping the promotion of national cadres that are at play independently of us. The promotion of national cadres is often met with strong opposition from certain arrivée comrades, who view it as an expression of chauvinism, etc. This kind of opposition is also encountered from certain Soviet all- Union ministries. We appeal to the Presidium of the CPSU CC with a request to uphold the measures aimed at the broader promotion of national cadres, and also to help with the dismissal of workers from the republic who have been discharged from their positions due to the promotion of national cadres, as there are no opportunities to offer these comrades work corresponding to their qualification level in the republic. ${ }^{49}$ Even though this document

${ }^{49}$ Letter from A. Sniečkus, dated 6 December 1956, to the CPSU CC, LYA, f. 16895 , ap. 2 , b. $314,1.7,8$. 
concerns the promotion of young cadres to leading positions, and their nationality is not explicitly mentioned, it is obvious that a reference is being made to young Lithuanian specialists.

The strong engagement of the rector of Kaunas University, and from 1950 the KPI, created the foundations for the re-Lithuanianisation of cadres mentioned above. It was not the letters from Antanas Sniečkus, the first secretary of the CPL CC, or other leaders sent to the university and the KPI, or the orders from the government of the republic to institutions of higher education, but the initiatives and activities of the rectors of these institutions that created a sufficient number of cadres ready to be Lithuanianised, and even their over-supply, allowing the leadership to implement a campaign of re-Lithuanianisation, and the expulsion of foreigners from Lithuania.

\section{Conclusions}

1. During Stalin's rule, the system of two universities, Vilnius and Kaunas, that had developed in Soviet Lithuania due to the historical geopolitical circumstances was exceptionally favourable for the ethnicisation (korenisation) of titular nation engineering specialists, compared to the situation in other Soviet republics. Even though the demand for new specialists from ministries and agencies was not very high, due to the institutional interests of Kaunas University, and from 1950 of the KPI, their rectors sought to ensure as large as possible a contingent of engineering students and graduates for employment in Lithuania. This activity implemented by the institutions of higher education caused the over-production of young engineers.

2. Research conducted for this article revealed that the governments of Soviet Lithuania and other republics, including neighbouring Latvia, saw to the training of national cadres and their employment in their respective republics. All of this points to the existence of support in the republics for the careers of the local nationality's specialists and leaders, which might not have contradicted, and even complied with, the Stalinist policy of the korenisation of titular nation cadres, and yet collided with the Soviet Union's higher education planning practices that exceeded the demands for trained specialists in each separate republic, and supported the inter-republic mobility of young specialists. Even though there were some similarities in the goals of separate republics, nonetheless, compared to neighbouring Latvia, we can see an important difference: if in Soviet Lithuania, the initial initiatives for the training of national engineering cadres 
came from institutions of higher education, then in Latvia these initiatives came from members of the government themselves.

3. In the second half of the 1940s and in the mid-1950s, the number of young trained engineers exceeded the demands of the republic's agencies and organisations, and became the foundation for the korenisation of Lithuanian nomenklatura cadres. The 'excess' contingent of engineers trained by the KPI became the base group of Lithuanian specialists that allowed the leaders of Soviet Lithuania to implement a policy of expulsion of Russian-speaking cadres from the republic.

\section{Author Details}

Saulius Grybkauskas is a postgraduate research worker at the Lithuanian Institute of History. In 2007 he defended the doctoral dissertation, 'Industrial management in Soviet Lithuania, 1965-1985: Tensions and Conflicts'. This article was prepared doing postgraduate research, 'The Second Secretary' in a Soviet Republic: The LCP CC Second Secretary and his Networks of Clients in Lithuania, 1940-1990". Address: Lithuanian Institute of History, 5 Kražiu St, Vilnius LT-01108, Lithuania. Email: grybkauskas@istorija.lt

\section{Bibliography}

BRAZAUSKAS, A. Ir tuomet dirbome Lietuvai: faktai, atsiminimai, komentarai (Vilnius, 2007).

BRUBAKER, R. Nationalism Reframed. Nationhood and the National Question in the New Europe (Cambridge, 1996).

ĖMUŽIS, M. Sovietų Lietuvos valdantysis elitas 1944-1974 metais: tarpusavio ryšiai ir ju raiška. Doctoral dissertation (Vilnius, 2016).

GENZELIS, B. 'Vytauto Didžiojo universiteto atkūrimo peripetijos', in: Kauno istorijos metraštis, no. 12 (2012).

GRYBKAUSKAS, S. Sovietinè nomenklatūra ir pramonès valdymas Lietuvoje 1965-1985 metais (Vilnius, 2011).

GRYBKAUSKAS, S., TAMOŠAITIS, M. Epochu virsmo sukūriuose. Algirdo Brazausko politine biografija (Vilnius, 2018).

GUDAVIČIUS, E., ŠVEDAS, A. Visa istorija yra gyvenimas. 12 sakytinès istorijos epizodų. Edvarda Gudavičiu kalbina Aurimas Švedas (Vilnius, 2008).

IVANAUSKAS, V. Lietuviškoji nomenklatura biurokartinejje sistemoje: tarp stagnacijos ir dinamikos (1968-1988) (Vilnius, 2011).

Stalininis režimas Lietuvoje 1944-1953 metais, ed. Regina Laukaitytè (Vilnius, 2014).

MARTYNAITIS, M., et al. Kazimieras Baršauskas (Vilnius, 1969).

MARTYNAITIS, M. Kauno Antano Sniečkaus Politechnikos institutas (Vilnius, 1979). 
TAMAŠAUSKAS, A. Iš Kauno universiteto politechnikos instituto praeities. Komunistu partinès organizacijos raidos ir veiklos apžvalga (Kaunas, 2000).

ZUBKOVA, E. Sovetskaya model ekonomiki: soyuznyi centr i respubliki pribaltiki $n 1953$ g. - mart 1965. Dokumenty (Moskva, 2015).

ЖДАНОВ, Ю.А. Взгляд в прошлое: воспоминания очевидия (Ростовна-Дону, 2004).

\section{TITULINĖS TAUTYBĖS INŽINIERIU SLUOKSNIO UGDYMAS SOVIETINĖSE LIETUVOJE IR LATVIJOJE XX A. 5 DEŠIMTMEČIO PABAIGOJE - 6 DEŠIMTMEČIO VIDURYJE}

Santrauka

\section{SAULIUS GRYBKAUSKAS}

Sovietmečiu inžinieriai sudarė didžiausią aukštajị išsilavinimą turinčių specialistų grupę. Jų skaičius ir dalies pradejo stipriai augti būtent 5 ir 6 dešimtmečiais, kada inžinierių skaičius prisivijo ir aplenkè iki tol skaičiumi pirmavusius gydytojus. Todèl svarbu yra giliau pažvelgti ị inžinierių socialinę grupę, jos formavimosi tautinį aspektą.

Šiame straipsnyje siekiama ištirti: 1) lietuvių inžinierių sluoksnio susiformavimo veiksnius, jų istorines geopolitines bei respublikos valdžios ir aukštujų mokyklų institucinių interesų sąlygojamas priežastis; 2) atskleisti „perteklinio“ lietuvių inžinierių rengimo reikšmę sovietinès Lietuvos valdžios vykdomai korenizacijos (paramos titulinès tautos atstovų karjerai) politikai.

J. Stalino valdymo laikotarpiu sovietineje Lietuvoje dèl istorinių geopolitinių aplinkybių susiklosčiusi dviejų universitetų - Vilniaus ir Kauno - sistema buvo išskirtinai palanki, lyginant su kitomis sovietinėmis respublikomis, specialistų etnizacijai (korenizacijai), titulinès tautos inžinierių ugdymui. Aukštųjų mokykla veikla, remiama sovietinès Lietuvos vadovų, sukèlè tam tikrą jaunų inžinieriu perprodukciją. XX amžiaus penktojo dešimtmečio antroje pusėje - šeštojo dešimtmečio viduryje parengtu jaunujų inžinierių skaičius viršijo respublikos ịstaigu ir organizacijų poreikị ir tapo lietuviškosios nomenklatūros kadrų korenizacijos kampanijos pagrindu. KPI parengtas „perteklinis“ inžinierių kontingentas tapo ta lietuviškų specialistų baze, kuri leido sovietinès Lietuvos vadovams vykdyti rusakalbių kadrų išsiuntimo iš respublikos politiką.

Atliktas tyrimas atskleidè, kad ne tik sovietinès Lietuvos, bet ir kitų respublikų, tarp jų ir kaimyninès Latvijos, valdžia rūpinosi nacionalinių kadrų parengimu ir jų įdarbinimu respublikoje. Visa tai rodo respublikose egzistavus paramą vietinès tautybès specialistų ir vadovų karjerai, kuri nors ir neprieštaravo ir net atitiko stalinistinę titulinių tautų kadrų korenizacijos politiką, tačiau kirtosi su sajunginès aukštojo mokslo sistemos planavimo praktikomis, specialistų rengime išeinančiomis už atskirų respublikų poreikių ir palaikančių tarprespublikini jaunų specialistų mobilumą. Nors panašumų respublikų siekiuose būta, vis dèlto, palyginti su kaimynine Latvija, galima įžvelgti svarbų skirtumą: sovietinejje Lietuvoje paramos nacionalinių inžinierių kadrų rengimui pirminès iniciatyvos èjo iš aukštojo mokslo institucijų, o Latvijoje - labiau iš pačių valdžios atstovų. 